\title{
Prehypertension: What to Do?
}

\section{Arvind K Pancholia}

\begin{abstract}
Prehypertension (PHTN) is a global health problem that carries the risk of being prone to developing hypertension in the future along with double the risk of cardiovascular disease (CVD). Its prevalence is 25 to $50 \%$ based on data from different countries, and it varies with age, sex, birth weight, and body mass index (BMI). Regarding its pathophysiology, several mechanisms have been proposed, but the most validated are Ras activation, oxidative stress, inflammatory cytokines, sympathetic overdrive, and central nervous system activation. Therapeutic lifestyle changes are the foundation for all therapies in prehypertensive patients, which are recommended by almost all guidelines. Drug therapy has also been tried in a couple of trials and is recommended in high-risk patients.
\end{abstract}

Keywords: Dietary approaches to stop hypertension diet, Hypertension, Sodium

How to cite this article: Pancholia AK. Prehypertension: What to Do? Hypertens J 2017;3(2):67-71.

Source of support: Nil

Conflict of interest: None

\section{INTRODUCTION}

In 1939, Robinson and Brucer suggested the value of clinically overt hypertension when the levels are 120 to $139 \mathrm{~mm} \mathrm{Hg}$ (systolic) and 80 to $89 \mathrm{~mm} \mathrm{Hg}$ (diastolic). ${ }^{1}$ Three decades later, it was termed as "borderline hypertension"; 2 then in 1997, it was changed to "high-normal blood pressure (BP)." ${ }^{3}$ The term "PHTN" was coined in 2003 by the seventh report of the Joint National Committee on Prevention, Detection, Evaluation, and Treatment of High Blood Pressure (JNC7). ${ }^{1}$ This report intended to identify those individuals in whom early intervention by healthy lifestyles could reduce BP and the rate of converting from PHTN to hypertension. The PHTN precedes clinical hypertension and is associated with increased incidence of CVD. ${ }^{2-4}$

\section{DEFINITION}

The PHTN is defined as a systolic BP (SBP) of 120 to $139 \mathrm{~mm} \mathrm{Hg}$ and/or a diastolic BP of 80 to $89 \mathrm{~mm} \mathrm{Hg}$.

\footnotetext{
Head

Department of Medicine and Preventive Cardiology, Arihant Hospital \& Research Centre, Indore, Madhya Pradesh, India

Corresponding Author: Arvind K Pancholia, Head, Department of Medicine and Preventive Cardiology, Arihant Hospital \& Research Centre, Indore, Madhya Pradesh, India, Phone: +919827027920, e-mail: drpancholia@gmail.com
}

Later on, the European Society of Cardiology (ESC) and the European Society of Hypertension (ESH) bifurcated it into normal (120-129 systolic and 80-84 diastolic) and high-normal (130-139 systolic and 85-89 diastolic). The ESH-ESC committee decided against using the term "PHTN" for several reasons:

- There is no reason to combine the two different groups because the risk of developing hypertension was definitely higher in those with high-normal BP than in patients with normal BP.

- The term "PHTN" can create anxiety in many subjects along with unnecessary medical visits and tests.

- Although lifestyle changes are recommended by the JNC7 for all PHTNs, this category is a highly differentiated one, with the extremes consisting of subjects with no need of any intervention.

\section{PREVALENCE}

The National Health and Nutrition Examination Survey (NHANES), 1999-2000 reported that the overall prevalence of PHTN was 31\% all over the world, which was higher in men than in women. ${ }^{5}$ A statistical analysis of disease-free adult NHANES participants, which was conducted from 1999 to 2006, found that the overall prevalence of PHTN in disease-free adults was $36.3 \%{ }^{6}$

Prevalence increases in people with $^{7}$

- Diabetes,

- Microalbuminuria,

- Chronic kidney disease (CKD),

- Heavy alcohol consumption, and

- Overweight/obese.

\section{Prevalence in India}

In a study from northern India, the reported prevalence of PHTN is $44 \%,{ }^{8}$ whereas a study in urban Chennai indicated a $47 \%$ prevalence of PHTN in adults $>18$ years. ${ }^{9}$ In another study, the reported prevalence is $40 \%$ in males and $30 \%$ in females. ${ }^{10}$ The statewise prevalence in India is shown in Graph 1.

\section{RISK FACTORS}

The risk factors are indicated in Table 1.

\section{WHY CARE FOR PHTN}

Patients with PHTN are at twice the risk of developing hypertension. ${ }^{11}$ The PHTN is also associated with 


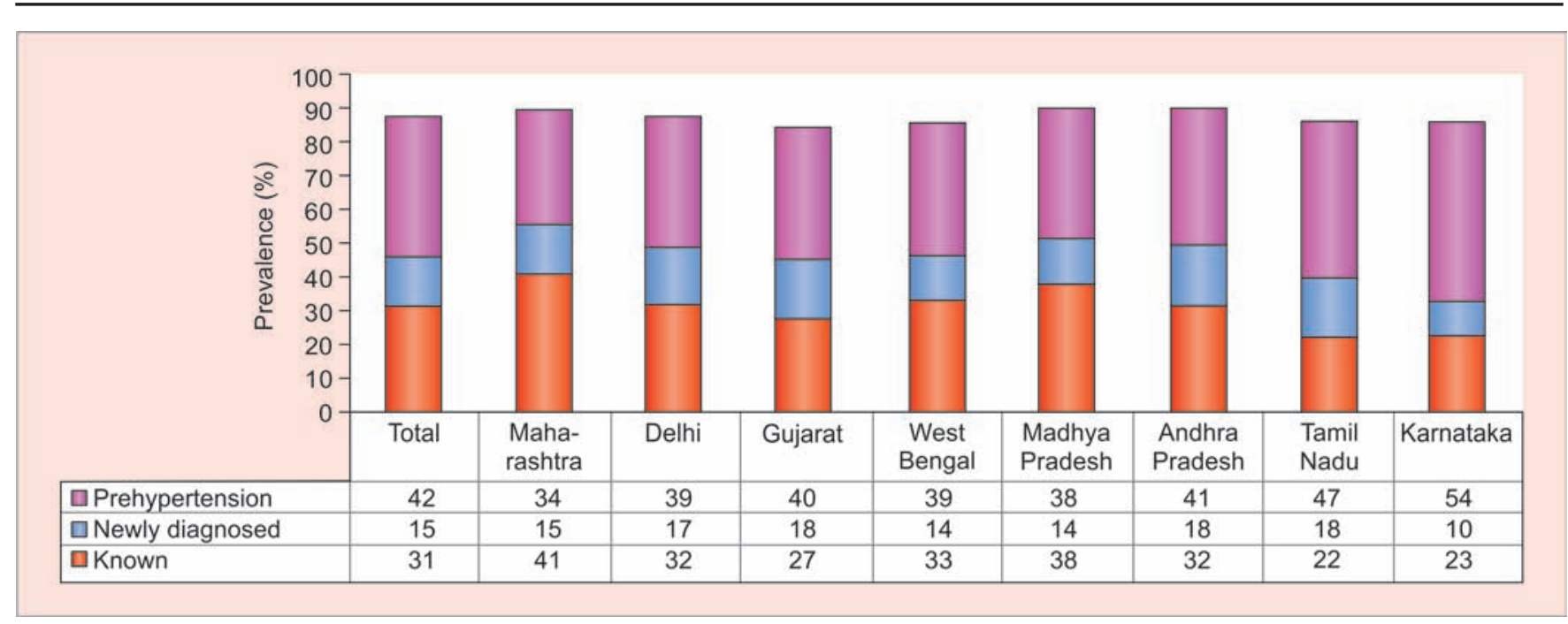

Graph 1: Statewise prevalence of PHTN in India

Table 1: Risk factors

\section{Overweight or obese}

Age: $>$ More in young patients

Sex: $M>F$

Black race

Family history

Lack of exercise

Diet high in salt (sodium) or low in potassium

Tobacco use

Alcohol

increased CVD. According to the Framingham study, there is increased risk of myocardial infarction by 3.5 fold and an increased risk of coronary artery disease by 1.7 fold $^{11}$ (Graph 2).

Results from the Strong Heart Study ${ }^{12}$ showed an increased risk of $\mathrm{CV}$ events when PHTN is associated with diabetes compared with diabetes or PHTN alone (Graph 3).

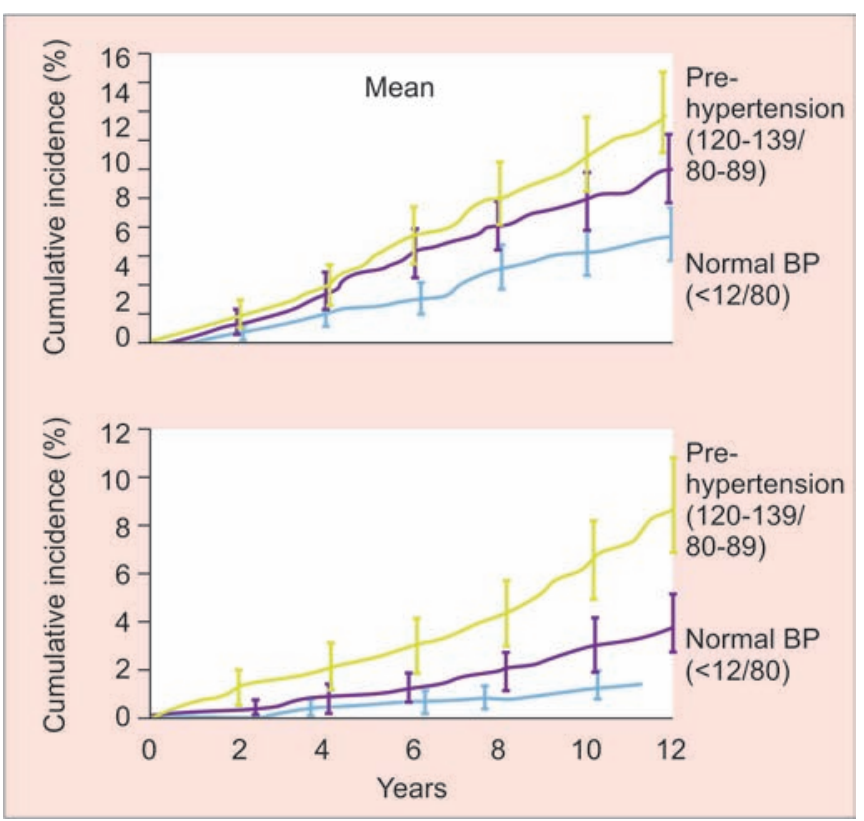

Graph 2: PHTN and CV risk (Source: Vasan et $\mathrm{al}^{11}$ )
The study also showed that $37 \%$ of prehypertensives will progress to hypertension over the next 4 years. There is a 2-fold increased risk of diabetes also in PHTN. Compared with a normal BP, PHTN is associated with a $27 \%$ increase in all causes of death and a $66 \%$ increase in cardiovascular deaths. ${ }^{13}$

Analysis from the CARDIA study suggests that PHTN in early adulthood leads to increased coronary calcium later in life. ${ }^{14}$ The PHTN is also associated with increased carotid intima thickness. ${ }^{15}$ There is increase in left ventricular (LV) mass index also with $\mathrm{PHTN}^{16}$ (Graph 4).

It is also associated with increased risk of CKD. ${ }^{17}$ A study also showed the worsening of renal function by 11 to $91 \%$ in prehypertensive individuals. Preexisting diabetes showed a strong relationship of PHTN and CKD risk. The basic pathophysiology for the development of CKD is the greater degree of renal arteriosclerosis and mesangial proliferation in prehypertensives. ${ }^{17}$ High-normal BP is associated with poor cognitive performance also. The relationship between BP and cognitive

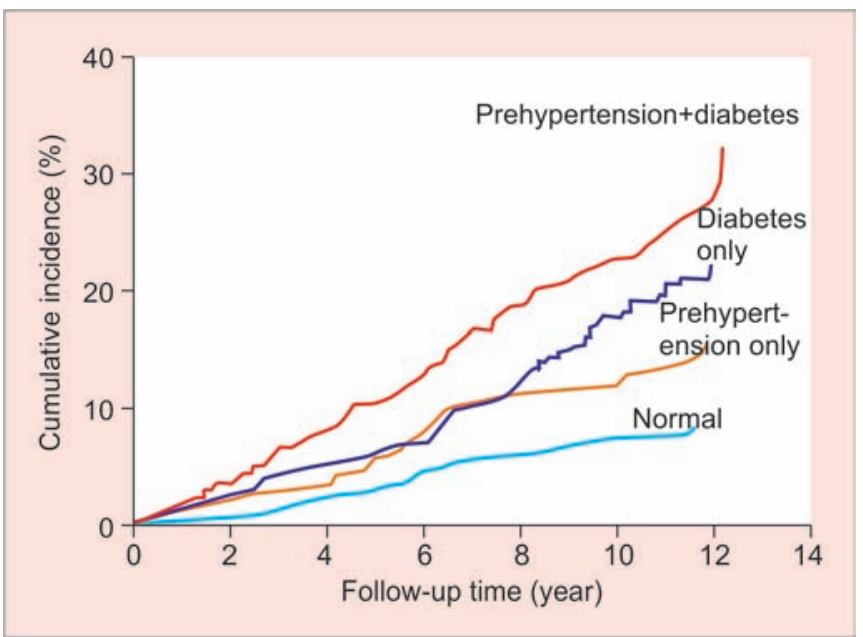

Graph 3: Strong heart study (Source: Segura and Ruilope ${ }^{12}$ ) 
Prehypertension: What to Do?

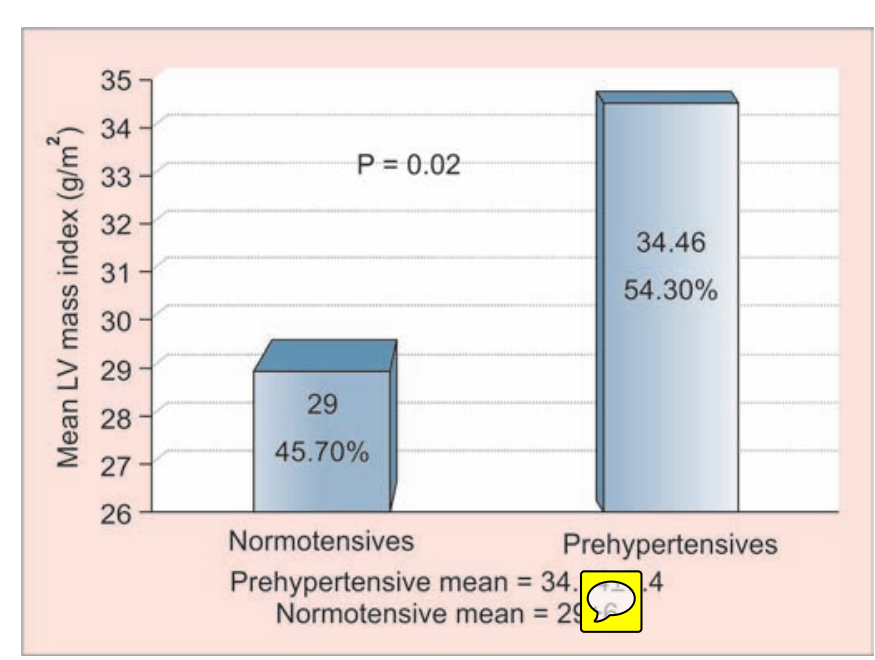

Graph 4: PHTN and LV mass index (Source: Mousa et al ${ }^{16}$ )

Table 2: Joint national committee 7 recommendations: Prehypertension lifestyle changes

\begin{tabular}{|c|c|c|}
\hline Items & Modifications & Effects on pressure \\
\hline $\begin{array}{l}\text { Sodium } \\
\text { intake }\end{array}$ & $\begin{array}{l}\text { Allowable maximum is } 2.4 \mathrm{gm} \\
\text { of sodium or } 6 \text { grams of } \\
\text { sodium chloride }\end{array}$ & $\begin{array}{l}5.1 / 2.7 \mathrm{~mm} \mathrm{Hg} \text { for } \\
1800 \mathrm{mg} / \text { day sodium } \\
\text { reduction }\end{array}$ \\
\hline $\begin{array}{l}\text { Weight } \\
\text { loss }\end{array}$ & $\begin{array}{l}\text { Maintain normal body weight } \\
\text { (body mass index } 18.5 \text { to } \\
\text { 24.9), per kg lost }\end{array}$ & $\begin{array}{l}1.1 / 0.9 \mathrm{~mm} \mathrm{Hg} \text { for } \\
1 \mathrm{~kg} \text { weight loss }\end{array}$ \\
\hline Alcohol & $\begin{array}{l}\text { Limit to } 2 \text { drinks/day men } \\
\text { (1 drink/day women \& } \\
\text { lightweight person) }\end{array}$ & 2 to $4 \mathrm{~mm} \mathrm{Hg}$ \\
\hline Exercise & $\begin{array}{l}\text { Do } 30 \text { minutes of aerobic } \\
\text { exercise for } 4 \text { to } 7 \text { days a } \\
\text { week }\end{array}$ & $\begin{array}{l}4.9 / 3.7 \mathrm{~mm} \mathrm{Hg} \text { for } \\
120 \text { to } 150 \text { minutes/ } \\
\text { week of exercise }\end{array}$ \\
\hline $\begin{array}{l}\text { Healthy } \\
\text { diet }\end{array}$ & $\begin{array}{l}\text { Take diet rich in fruits, } \\
\text { vegetables }\end{array}$ & $11.4 / 5.5 \mathrm{~mm} \mathrm{Hg}$ \\
\hline
\end{tabular}

performance is linear, even in normotensive and prehypertensive ranges. ${ }^{18}$ The PHTN also predicts pregnancyinduced hypertension and its postpartum progression. ${ }^{19}$ The PHTN is also linked with metabolic syndrome and CVD (Flow Chart 1).

\section{PATHOPHYSIOLOGY}

Many hypotheses are proposed to explain the underlying pathophysiology of PHTN.

- Renin-angiotensin-aldosterone system activation

- Oxidative stress

- Inflammation Sympathetic nervous system activation

- Central mechanism

\section{PHTN: WHAT TO DO ?}

\section{Therapeutic Lifestyle Changes}

Practically all the guidelines, previous ${ }^{3}$ and recent guidelines, ${ }^{20}$ recommend specific lifestyle modifications for
Flow Chart 1: Cardiometabolic syndrome and link with CVD (Source: Expert Rev Cardiovasc Ther 2013)

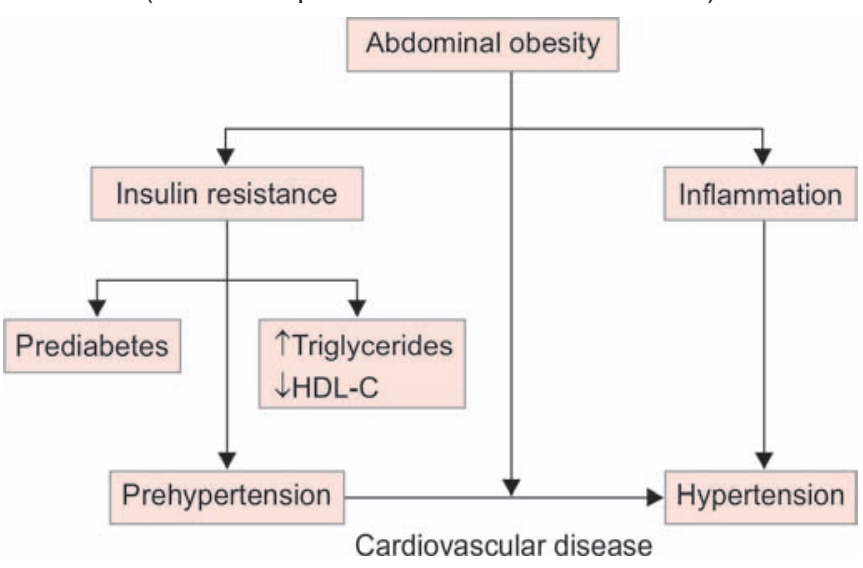

Table 3: DASH diet
PHTN. The most recent recommendations (JNC7 report) ${ }^{4}$ are as follows:

- Maintaining BMI between 18.5 and $24.9 \mathrm{~kg} / \mathrm{m}^{2}$; this is expected to reduce SBP by 5 to $20 \mathrm{~mm} \mathrm{Hg}$ for each $10-\mathrm{kg}$ reduction in weight.

- Consuming more fruits and vegetables in diet; this is expected to reduce SBP by 8 to $14 \mathrm{~mm} \mathrm{Hg}$.

- Restricting sodium to no more than $6 \mathrm{gm}$ of table salt per day; this is expected to reduce SBP by 2 to $8 \mathrm{~mm} \mathrm{Hg}$

- Brisk walking for at least 30 minutes per day or regular aerobic physical activity; this is expected to reduce SBP by 4 to $9 \mathrm{~mm} \mathrm{Hg}$.

- Reducing alcohol consumption; this reduces SBP by 2 to $4 \mathrm{~mm} \mathrm{Hg}$ (Table 2).

Dietary Approaches to Stop Hypertension (DASH) diet plan ${ }^{21}$ (Table 3), which uses a diet rich in fruits, vegetables, legumes, nuts, and low-fat dietary products and low saturated fats, has a significant lowering of BP. The DASH diet can reduce BP by 8 to $14 \mathrm{~mm} \mathrm{Hg}$, an effect that was augmented even further when dietary sodium was restricted. 


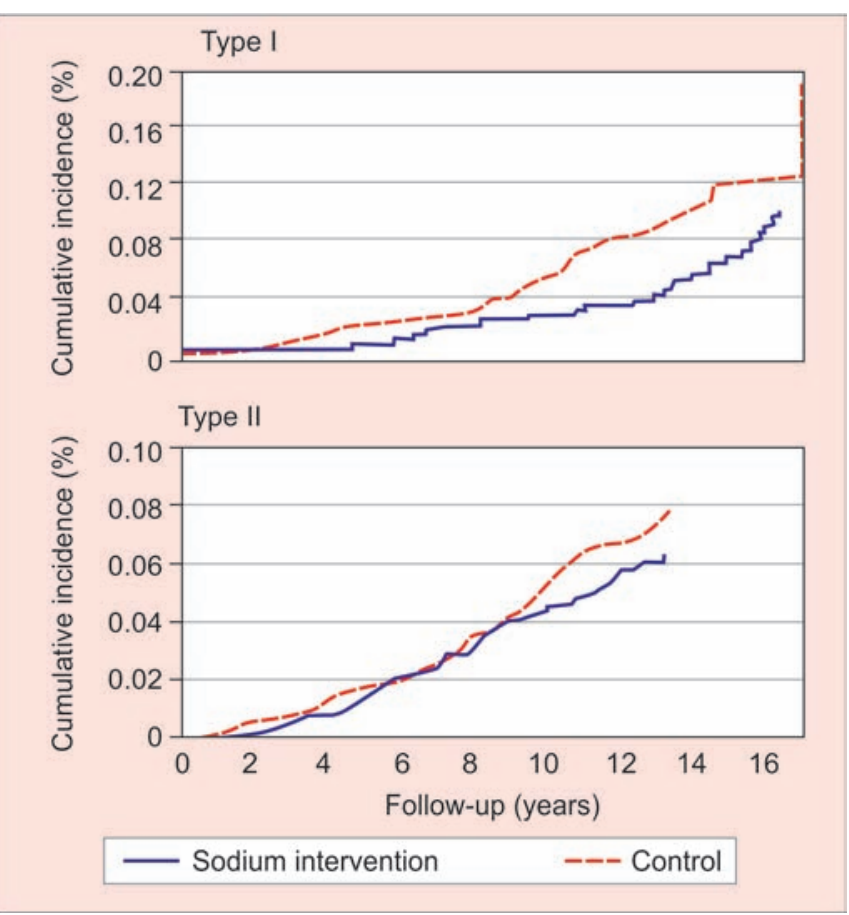

Graph 5: Cumulative incidence of CVD by sodium intervention group in TOHP I and II (Source: Cook NR et al. ${ }^{23}$

The OmniHeart Collaborative Research Group study ${ }^{22}$ in which the DASH diet was modified to provide more protein and unsaturated fat and less carbohydrate showed impressive reductions of BP. The Trials of Hypertension Prevention (TOHP) I and TOHP II trials ${ }^{23}$ (Graph 5) showed that dietary sodium reduction for 18 months (TOHP 1) or for 36 to 48 months (TOHP II) reduces the primary end points (myocardial infarction, stroke, coronary revascularization, or cardiovascular-related death) in middle-aged individuals with PHTN by $25 \%$ lower compared with placebo group. The PREMIER trial ${ }^{24}$ demonstrated that multicomponent behavioral interventions with and without the DASH diet produced significant reductions in the 10-year risk of coronary heart disease in subjects with PHTN.

\section{PHARMACOTHERAPY}

The primary approach to treat PHTN is therapeutic lifestyle changes, which have been recommended by several guidelines. Pharmacotherapy is recommended mainly in high-risk groups with CVD and CKD. However, there is still no consensus. Few trials have been done with different pharmacological agents with mixed results.

The Trial of Preventing Hypertension (TROPHY) study evaluated the effect of angiotensin II receptor antagonist candesartan cilexetil on the prevention of PHTN progressing to stage 1 hypertension ${ }^{25}$ (Graph 6). After 4 years, stage 1 hypertension developed in two-thirds of patients in the placebo group, while in the intervention group, there was $66 \%$ reduction in the risk of development of incident hypertension.

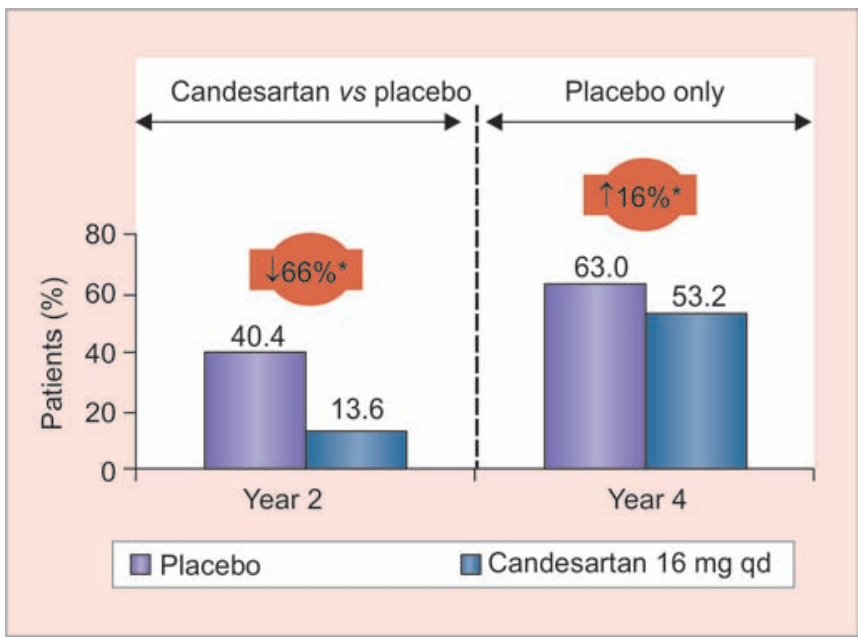

Graph 6: TROPHY: Reduction in new-onset hypertension (Source: Julius et $\mathrm{al}^{25}$ )

The PHARAO study is the prevention of hypertension with the angiotensin-converting enzyme inhibitor Ramipril in patients with high-normal $\mathrm{BP}$ - a prospective, randomized, controlled prevention trial of the German Hypertension League. ${ }^{26}$ The study showed significant reduction in the risk of progression to manifest hypertension by $34.4 \%$.

The PREVER prevention $\operatorname{trial}^{27}$ is the combination of chlorthalidone and amiloride in prehypertensive patients that effectively reduces the risk of incident hypertension and beneficially affects LV mass. After 18 months, the incidence of hypertension was $11.7 \%$ in the diuretic arm vs $19.5 \%$ in the placebo arm.

\section{Follow-up of Prehypertensive Patients}

Subjects with PHTN need to be treated and evaluated every month or two, until the BP goal is reached and then every 3 to 6 months thereafter. Subjects with complications/end organ damage, such as heart or kidney disease may need to be evaluated more frequently at regular intervals.

\section{CONCLUSION}

- Prehypertension is a common problem in the community.

- Its prevalence is on the rise.

- It is associated with increased risk of hypertension, target organ damage, and CVD.

- Healthy lifestyle is the foundation for all therapies in persons with PHTN.

- Drug therapies have been tried, but there is no convincing evidence that antihypertensive therapy changes the course of PHTN.

\section{REFERENCES}

1. Robinson SC, Brucer M. Range of normal blood pressure: a statistical and clinical study of 11,383 persons. Arch Int Med 1939 Sep;64(3):409-444. 
2. Julius S, Schork MA. Borderline hypertension-a critical review. J Chronic Dis 1971 Mar;23(10):723-754.

3. The sixth report of the Joint National Committee on prevention, detection, evaluation, and treatment of high blood pressure. Arch Intern Med 1997 Nov 24;157(21):2413-2446.

4. Chobanian AV, Bakris GL, Black HR, Cushman WC, Green LA, Izzo JL, Jones DW, Materson BJ, Oparil S, Wright JT, et al. The Seventh Report of the Joint National Committee on Prevention, Detection, Evaluation, and Treatment of High Blood Pressure: the JNC 7 report. JAMA 2003 May 21;289(19):2560-2572.

5. Wang Y, Wang QJ. The prevalence of prehypertension and hypertension among US Adults According to the New Joint National Committee Guidelines: new challenges of the old problem. Arch Intern Med 2004 Oct 25;164(19):2126-2134.

6. Gupta AK, McGlone M, Greenway FL, Johnson WD. Prehypertension in disease-free adults: a marker for an adverse cardiometabolic risk profile. Hypertens Res 2010 Sep;33(9):905-910.

7. Glasser SP, Judd S, Basile J, Lackland D, Halanych J, Cushman M, Prineas R, Howard V, Howard G. Prehypertension, racial prevalence and its association with risk factors: analysis of the REasons for Geographic And Racial Differences in Stroke (REGARDS) study. Am J Hypertens 2011 Feb;24(2):194-199.

8. Prabhakaran D, Shah P, Chaturvedi V, Ramakrishnan L, Manhapra A, Reddy KS. Cardiovascular risk factor prevalence among men in a large industry of northern India. Natl Med J India 2005 Mar-Apr;18(2):59-65.

9. Yadav S, Boddula R, Genitta G, Bhatia V, Bansal B, Kongara S, Julka S, Kumar A, Singh HK, Ramesh V, et al. Prevalence \& risk factors of pre-hypertension \& hypertension in an affluent north Indian population. Indian J Med Res 2008 Dec;128(6):712-720.

10. Gupta R, Deedwania PC, Achari V, Bhansali A, Gupta BK et al. Normotension, prehypertension, and hypertension in urban middle-class subjects in India: prevalence, awareness, treatment, and control. Am J Hypertens. 2013 Jan;26(1):83-94.

11. Vasan RS, Beiser A, Seshadri S, Larson MG, Kannel WB, D'Agostino RB, Levy D. Residual lifetime risk for developing hypertension in middle-aged women and men: the Framingham Heart Study. JAMA 2002 Feb 27;287(8):1003-1010.

12. Segura J, Ruilope LM. Treatment of prehypertension in diabetes and metabolic syndrome. Diabetes Care 2009 Nov;32(Suppl 2):S284-S289.

13. Urbina EM, Khoury PR, McCoy C, Daniels SR, Kimball TR, Dolan LM. Cardiac and vascular consequences of prehypertension in youth. J Clin Hypertens (Greenwich) 2011 May;13(5):332-342.

14. Pletcher MJ, Bibbins-Domingo K, Lewis CE, Wei GS, Sidney S, Carr JJ, Vittinghoff E, McCulloch CE, Hulley SB. Prehypertension during young adulthood and coronary calcium later in life. Ann Intern Med 2008 Jul 15;149(2):91-99.
15. Mandal BC, Pramanik SP, Bag A, Sarkar N. Impact of prehypertension on carotid artery intima media thickness. IOSR J Pharm 2014 Apr;4(4):8-10.

16. Mousa TM, Akinseye OA, Berekashvili K, Akinboboye OO. Correlation of prehypertension with left ventricular mass assessed by cardiac magnetic resonance imaging. Int J Hypertens 2015;2015: 742658.

17. Kidney International. International Society of Nephrology; 2010.

18. KnechtS, Wersching H, Lohmann H, Bruchmann M, Duning T, Dziewas R, Berger K, Ringelstein EB. High-normal blood pressure is associated with poor cognitive performance. Hypertension 2008 Mar;51(3):663-668.

19. Makino S, Iwata A, Seki H, Takeda S. Pre-hypertension predicts pregnancy induced hypertension and its postpartum progression. Hypertens Res Pregnancy 2013;(1):71-74.

20. Egan BM, Nesbitt SD, Julius S. Prehypertension: should we be treating with pharmacologic therapy? Ther Adv Cardiovasc Dis 2008 Aug;2(4):305-314.

21. Sacks FM, Svetkey LP, Vollmer WM, Appel LJ, Bray GA, Harsha D, Obarzanek E, Conlin PR, Miller ER, SimonsMorton DG, et al. Effects on blood pressure of reduced dietary sodium and the Dietary Approaches to Stop Hypertension (DASH) diet. DASH-Sodium Collaborative Research Group. N Engl J Med 2001 Jan 4;344(1):3-10.

22. Appel LJ, Sacks FM, Carey VJ, Obarzanek E, Swain JF, Miller ER, Conlin PR, Erlinger TP, Rosner BA, Laranjo NM, et al. Effects of protein, monounsaturated fat, and carbohydrate intake on blood pressure and serum lipids: results of the OmniHeart randomized trial. JAMA 2005 Nov 16;294(19):2455-2464.

23. Stevens VJ, Corrigan SA, Obarzanek E, Bernauer E, Cook NR, Hebert P, Mattfeldt-Beman M, Oberman A, Sugars C, Dalcin AT. Weight loss intervention in phase 1 of the Trials of Hypertension Prevention. The TOHP Collaborative Research Group. Arch Intern Med 1993 Apr 12;153(7):849-858.

24. Appel LJ, Champagne CM, Harsha DW, Cooper LS, Obarzanek E, Elmer PJ, Stevens VJ, Vollmer WM, Lin PH, Svetkey LP, et al, Effects of comprehensive lifestyle modification on blood pressure control: main results of the PREMIER clinical trial. JAMA 2003 Apr 23-30;289(16):2083-2093.

25. Julius S, Nesbitt SD, Egan BM, Weber MA, Michelson EL, Kaciroti N, Black HR, Grimm RH Jr, Messerli FH, Oparil S, et al. Feasibility of treating prehypertension with an angiotensinreceptor blocker. N Engl J Med 2006 Apr 20;354(16):1685-1697.

26. Lüders S, Schrader J, Berger J, Unger T, Zidek W, Böhm M, Middeke M, Motz W, Lübcke C, Gansz A, et al. PHARAO Study Group: prevention of hypertension with the angiotensin-converting enzyme inhibitor ramipril in patients with high-normal blood pressure: a prospective, randomized, controlled prevention trial of the German Hypertension League. J Hypertens 2008 Jul;26(7):1487-1496.

27. Fuchs SC, Carlos E. Poli-de-Figueiredo. Effectiveness of Chlorthalidone Plus Amiloride for the prevention of Hypertension: The PREVER trial. J Am Heart Assoc 2016;5:e004248. 